\title{
Mengadopsi Model Akuntansi Startup untuk UMKM: Studi Kasus pada Pengerajin Kayu Desa Grenden, Kabupaten Jember
}

\author{
Luh Putu Indah Budyawati ${ }^{1}$, Arie Rahayu Hariani ${ }^{2}$, Wiwin Hartanto ${ }^{1}$ \\ FKIP1 FEB $^{2}$ Universitas Jember \\ arierahayu@unej.ac.id
}

\begin{abstract}
Abstrak
Saat ini, tidak banyak usaha mikro, kecil, dan menengah (UMKM) yang menyusun laporan keuangan. ${ }^{1}$ Padahal laporan keuangan berguna tidak hanya sebagai bentuk akuntabilitas pada pihak eksternal yang berkepentingan, namun juga bagi para pemilik dan pengelola UMKM itu sendiri. Manfaat laporan keuangan secara manajerial antara lain untuk perencanaan, mengetahui posisi keuangan, menilai kinerja, serta membantu pengambilan keputusan bisnis yang relevan. Ketidakpopuleran laporan keuangan di kalangan UMKM ini salah satunya disebabkan oleh model penyusunan laporan keuangan yang memang relatif kompleks. Oleh karena itu, kegiatan pengabdian kepada masyarakat ini bertujuan mengenalkan model akuntansi startup kepada UMKM, yang dalam hal ini para pengerajin kayu di Desa Grenden, Kabupaten Jember. Pemilihan model akuntansi startup sendiri dilakukan karena model akuntansi ini relatif sangat sederhana dengan metriks yang berbasis bisnis sehingga relatif lebih mudah dipahami pelaku UMKM pada umumnya. Desain penelitian berupa metode penelitian kualitatif deskriptif dengan subjek UMKM pengerajin kayu di Desa Grenden, Kabupaten Jember. Metode ini dipilih dengan harapan mampu lebih menangkap beragam nuansa yang muncul selama pengerajin kayu Desa Grenden mencoba menggunakan model akuntansi startup. Penelitian ini bertujuan untuk mengetahui apakah keengganan UMKM untuk menyiapkan laporan keuangan bisa dipecahkan dengan menawarkan model akuntansi yang lebih simpel dan lebih mudah dipahami pelaku bisnis yaitu model akuntansi startup. Pada studi ini ditemukan bahwa keengganan pelaku UMKM, dalam hal ini pengerajin kayu di desa Grenden, memang diakibatkan oleh kompleksnya model akuntansi konvensional yang digunakan untuk menyusun laporan keuangan. Sementara itu, model akuntansi startup yang memang lebih simpel dengan metriks berbasis bisnis memang dianggap lebih bermanfaat dan lebih mudah diterima oleh para pelaku UMKM. Kondisi yang serupa antara model bisnis startup dengan UMKM tertentu juga memungkinkan UMKM untuk memanfaatkan model akuntansi startup. Namun demikian, meskipun secara umum dianggap bermanfaat, penerapan model akuntansi startup juga perlu mempertimbangkan sejumlah hal seperti kemampuan pelaku UMKM dalam menggunakan teknologi informasi sederhana agar lebih banyak diterima dan digunakan oleh masyarakat.
\end{abstract}

Kata kunci: Akuntansi Startup, UMKM, Pengerajin Kayu

\begin{abstract}
Nowadays, there were not many UMKM that prepare financial statement. ${ }^{2}$ This is despite the fact that financial statements was useful, not only as an accountability to the stakeholders, but also to the owners and managers of UMKM. Financial statements can be very useful to management in planning, understanding financial position, assessing performance, and supporting relevant business decision. The reason financial statements were not that popular in UMKM was the complex and difficult nature of accounting and financial statement preparation.

\footnotetext{
Arifin, Nurul. 2018. "Masih Banyak Pelaku UMKM 'Buta’ Akuntansi”. Kompas. Diakses pada Oktober 2019 https://ekonomi.kompas.com/read/2018/08/30/144531526/masih-banyak-pelaku-umkm-butaakuntansi

2 Ibid.
} 
It is why this activity aimed to introduce startup accounting model to UMKM, which in this case are the carpenters in Desa Grenden, Kabupaten Jember. The choice of startup accounting model itself was done because this accounting model was relatively very simple with business based metrics so it was relatively easier to be understood by the UMKM. We used descriptive qualitative method for our research design. This method was chosen because we hope to capture more nuance in the period UMKM attempted to use the startup accounting model. This research aim to understand if UMKM resistance to prepare financial statements could be solved by offering accounting model which is simpler and easier to understand by UMKM which in this case is startup accounting model. This study found that UMKM resistance, in this case the carpenters in Desa Grenden, was indeed caused by the complexity of conventional accounting model which is used to prepare financial statements. Meanwhile, startup accounting model which was simpler with business-based metrics was indeed perceived to be more useful and more acceptable by UMKM. Similar conditions between startup business model with certain UMKM also allow UMKM to use startup accounting model. In this case, even though generally regarded as beneficial, the implementation fo startup accounting model also need to consider several other things like UMKM capability in using simple information technology so it become more acceptable and widely used by the small businesses.

Keywords: Startup Accounting, UMKM, Carpenters

\section{PENDAHULUAN}

Desa Grenden yang terletak di Kecamatan Puger, Kabupaten Jember ini memiliki masyarakat dengan mata pencaharian yang cukup beragam. Salah satu mata pencaharian yang cukup banyak diminati warga adalah pengerajin kayu. Hal ini dikarenakan wilayah hutan di daerah yang relatif luas. Namun demikian, banyak pengerajin kayu di Desa Grenden memiliki penghasilan yang belum stabil. Hal ini dikarenakan permintaan furnitur yang relatif tidak banyak serta keterbatasan jangkauan pengerajin kayu Desa Grenden sehingga terbatas hanya mengerjakan pesanan furnitur yang sifatnya lokal.

Hal ini mempengaruhi kesejahteraan warga Desa Grenden karena suatu bengkel kerajinan kayu biasanya mempekerjakan beberapa warga sekitar. Bila sedang tidak ada pekerjaan, banyak warga yang awalnya ikut bekerja di bengkel akhirnya bekerja di produksi gamping yang memang menyediakan banyak lapangan pekerjaan. Ini kemudian membuat bengkel kerajinan kayu kemudian kesulitan mengerjakan pesanan yang ada karena kurangnya pekerja yang terampil dan handal. Waktu kerja (siklus produksi) pun menjadi lebih lama. Pesanan butuh waktu yang lebih lama untuk diselesaikan yang berakibat produksi kurang optimal dan konsumen kurang puas. Ini berakibat pada berkurangnya pesanan furnitur lebih lanjut.

Model produksi yang menyulitkan pengerajin kayu di Desa Grenden ini mendorong mereka untuk berdiversifikasi dan mencoba mengembangkan diri ke usaha lain yang sejenis. Ada sejumlah usaha baru yang pernah dikembangkan oleh para pengerajin kayu Desa Grenden. Di antaranya pagar, hiasan dari semen, furnitur rustik, dan sebagainya. Salah satu yang terbaru yang mereka kembangkan adalah alat permainan edukasi (APE) yang terbuat dari kayu. Para pengrajin memilih untuk mengembangkan APE ini karena nilai jualnya yang tinggi dengan modal yang relatif sedikit sehingga memberikan potensi keuntungan yang cukup menarik. 


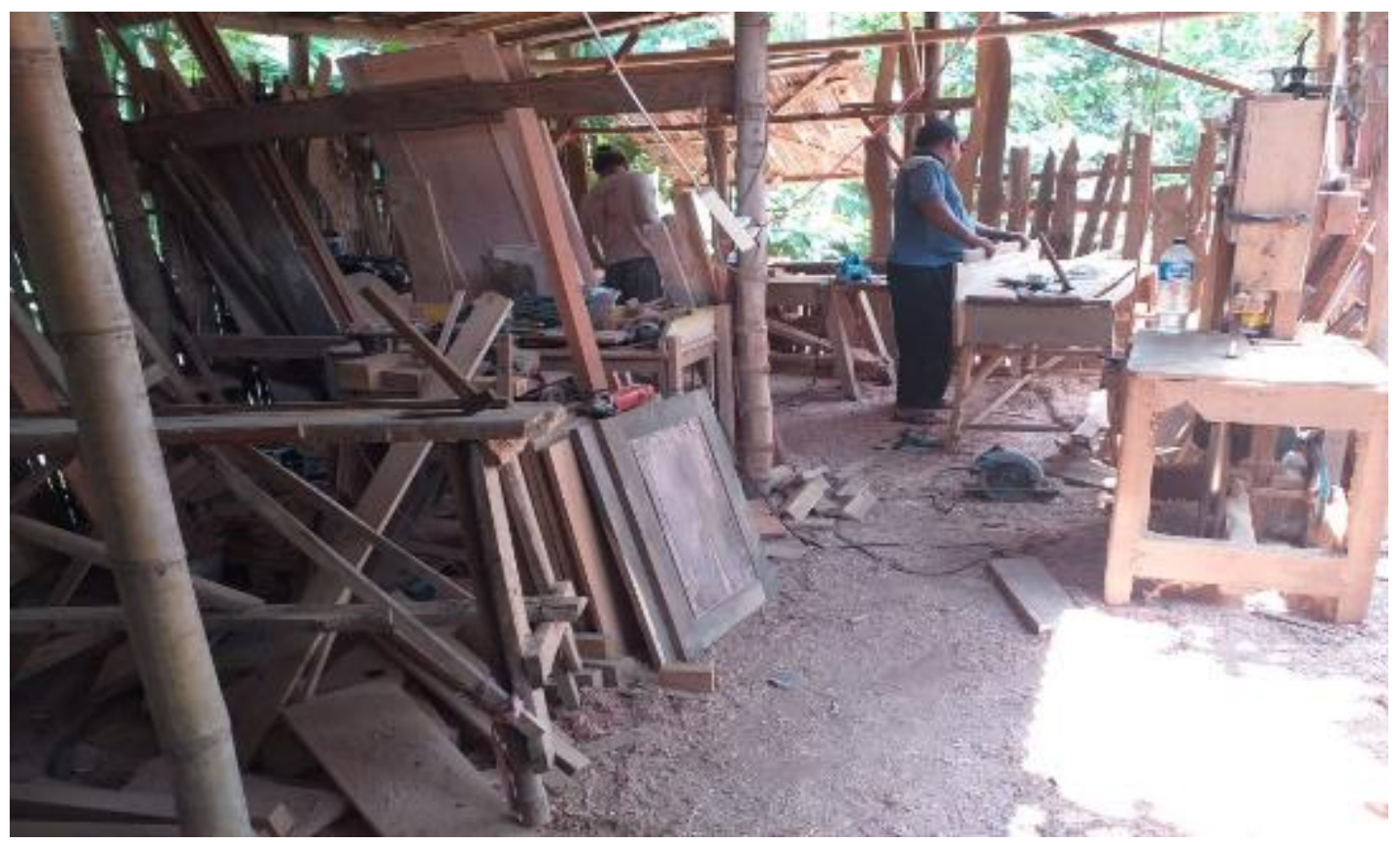

Namun demikian, mengembangkan usaha baru bukanlah hal yang mudah dilakukan. ${ }^{3}$ Secara umum, mengembangkan usaha baru memiliki tingkat keberhasilan yang kecil, bahkan lebih kecil dibandingkan daripada ketika bisnis yang mapan membuka usaha baru. Hal ini terkait dengan karakter pendiri dan model pengembangannya itu sendiri. Salah satu model pendukung pengembangan usaha yang banyak digunakan adalah akuntansi dengan laporan keuangan sebagai hasil akhirnya. Namun demikian, Steve Blank (2010) mengawali wacana bahwa startup, yang juga merupakan salah satu jenis usaha baru, tidak membutuhkan akuntansi atau, paling tidak, model akuntansi yang umumnya digunakan. ${ }^{4}$

Hal ini dikarenakan bentuk usaha saat ini cenderung ramping, yang sering disebut dengan lean startup. ${ }^{5}$ Usaha yang ramping ini cenderung membutuhkan modal yang lebih sedikit, model bisnis yang belum pasti, pendiri atau pemilik yang cenderung menjalankan semua bagian bisnisnya. Dengan model usaha yang seperti ini maka yang diperlukan bukanlah model akuntansi konvensional yang cenderung menekankan pada efisiensi usaha melainkan justru model akuntansi yang bisa mendukung penjelajahan usaha dan modelnya (eksploratori).

Sifat eksploratori dari model usaha lean startup inilah yang kemudian mendorong Steve Blank (2010) untuk membuat rerangka pikir akuntansi baru yaitu model akuntansi startup. ${ }^{6}$ Model ini menekankan pada ukuran berbasis bisnis sederhana yang mudah dipahami dan digunakan oleh orang non-akuntansi sekalipun. Selain itu, yang lebih

Xi, Guoqian. 2017. "How Does Firm Survival Differ between Business Takeovers and New Venture Start-Ups." IZA Discussion Paper. No. 11155.

4 Blank, Steve. 2010. "No Accounting for Startups". Blog post. Diunduh pada Oktober 2019 di https://steveblank.com/2010/02/22/no-accounting-for-startups/

5 Blank, Steve. 2013. "Why the Lean Startup Changes Everything." Harvard Business Review. May 2013 6 Ibid. 
utama, model akuntansi startup ini memfasilitasi sifat eksploratori dari suatu usaha baru dengan mengoptimalkan ukuran modal kerja (cash burn rate) dan kinerja berbasis potensi pertumbuhan (customer retention rate). Model akuntansi startup ini kemudian banyak digunakan oleh dan berhasil di startup Amerika.

Hal yang menarik adalah model lean startup yang dijadikan basis untuk mengembangkan model akuntansi startup ini memiliki sejumlah kesamaan dengan beberapa model usaha mikro, kecil, dan menengah (UMKM). Hal ini mungkin lebih dikarenakan kesamaan sifat usaha dan siklus bisnis yang sama-sama dijalani oleh startup dan oleh UMKM. Oleh karena itu, dalam perjalanannya model akuntansi startup ini juga bisa digunakan oleh UMKM. Ini akan sangat berguna bagi UMKM karena banyak UMKM yang tidak membuat pelaporan akuntansi. Sebagian besarnya malah sama sekali tidak tahu-menahu soal akuntansi (Kompas 2018). Padahal model penilaian atau review kinerja sangatlah penting bagi UMKM untuk merencanakan masa depannya, membuat keputusan strategis, dan mencari keunggulan kompetitif yang dapat digunakan untuk mengembangkan diri lebih lanjut.

Oleh karena itu, kegiatan pengabdian kepada masyarakat ini bertujuan untuk mengenalkan, memahamkan, dan memampukan sejumlah pengerajin kayu di Desa Grenden untuk menggunakan dan memanfaatkan model akuntansi startup melalui pelatihan dan pendampingan. Program ini merupakan awalan kegiatan yang dilakukan dengan harapan agar pengerajin kayu di Desa Grenden mampu mengelola usahanya dengan baik dan mampu melakukan review kinerja.

\section{A. Rumusan Masalah}

Rumusan masalah untuk kegiatan pengabdian kepada masyarakat ini adalah bagaimana pengerajin kayu dapat lebih baik dalam mengembangkan usaha awalnya dengan pendampingan dan pelatihan model akuntansi startup?

\section{B. Tujuan}

Kegiatan pengabdian kepada masyarakat ini bertujuan untuk memungkinkan pengerajin kayu lebih baik dalam mengembangkan usaha awalnya dengan memberikan pendampingan dan pelatihan model akuntansi startup.

\section{METODE PELAKSANAAN}

Metode yang digunakan dalam program pengabdian kepada masyarakat ini adalah pelatihan dan pendampingan. Pelatihan dan pendampingan ini diikuti oleh sejumlah pengerajin kayu di Desa Grenden. Kegiatan ini diharapkan mengenalkan, memahamkan, dan memampukan pengerajin kayu di Desa Grenden untuk menggunakan dan memanfaatkan model akuntansi startup untuk pengembangan usahanya.

Kegiatan pelatihan dan pendampingan ini akan dilakukan sesuai dengan kesepakatan dengan warga. Untuk awal akan dilakukan musyawarah dengan pejabat 
dan perwakilan desa. Bila ide ini dapat diterima maka akan dilakukan pelatihan model akuntansi startup di balai Desa Grenden dengan pengerajin kayu Desa Grenden sebagai peserta. Apabila pengerajin kayu tertarik dengan model akuntansi startup ini maka akan dilakukan pendampingan lebih lanjut yang bertempat di bengkel kerajinan kayu para pengrajin.

\section{A. Waktu dan Tempat Kegiatan}

Ada dua tipe kegiatan dalam program pengabdian kepada masyarakat ini. Kegiatan pertama berupa pelatihan model akuntansi startup. Kegiatan ini bertujuan mengenalkan model akuntansi startup pada para pengerajin kayu di Desa Grenden. Pelatihan akan membahas konsep-konsep umum yang ada di model akuntansi startup.

Tipe kegiatan kedua adalah pendampingan model akuntansi startup. Kegiatan ini bertujuan memampukan para pengerajin kayu di Desa Grenden untuk menggunakan dan memanfaatkan model akuntansi startup khususnya dalam usaha pengembangan bisnisnya. Kegiatan ini terkait konteks yaitu membahas hal-hal spesifik model akuntansi startup untuk pengembangan bengkel kerajinan kayu sesuai dengan masalah dan situasi yang dihadapi masing-masing bengkel.

Berdasarkan kedua tipe kegiatan tersebut maka program pengabdian kepada masyarakat ini diselenggarakan mulai bulan Oktober - Desember 2019. Sementara itu tempat kegiatan adalah di Desa Grenden, baik itu di balai desa maupun di bengkel kerajinan kayu peserta.

\section{B. Tahapan Kegiatan}

Program pengabdian kepada masyarakat ini memiliki sejumlah tahapan kegiatan.

\section{Tahapan Persiapan}

Dalam tahapan persiapan, tim program pengabdian kepada masyarakat mempelajari beberapa metode studi kasus yang akan diterapkan untuk mengetahui hal-hal yang diperlukan untuk pada akhirnya memampukan pengrajin kayu di Desa Grenden untuk menggunakan dan memanfaatkan model akuntansi startup. Kegiatan yang dilakukan adalah sebagai berikut:

a. Pengamatan - Tim program pengabdian kepada masyarakat melakukan pengamatan permulaan terhadap masyarakat pengerajin kayu di Desa Grenden, Kabupaten Jember. Para pengerajin kayu ini mencoba mengembangkan bisnis dengan memulai mencoba memproduksi alat permainan edukasi (APE). Pengamatan dilakukan atas cara berpikir, keberterimaan mereka terhadap ide untuk mencoba memproduksi APE, pendapat mereka secara umum tentang pelaporan akuntansi, serta ketertarikan mereka mencoba hal baru seperti model akuntansi startup. Hal ini berguna untuk melihat seberapa paham dan antusias masyarakat pengrajin kayu atas konsep bisnis, pengembangan bisnis, dan akuntansi. Yang ideal adalah bila masyarakat memiliki pemahaman konsep serta antusiasme yang baik dalam ketiga hal tersebut. 
b. Wawancara - Dalam konsep pemanfaatan akuntansi sehari-hari, sangatlah penting agar calon pengguna mampu mengaitkan antara fenomena bisnis yang terjadi dengan ukuran akuntansi yang digunakan beserta dengan interpretasinya. Oleh karena itu, tim program pengabdian kepada masyarakat akan melakukan wawancara terhadap masyarakat pengerajin kayu mengenai model bisnis yang mereka pilih untuk mencoba mengembangkan bisnis beserta perlunya pelaporan akuntansi. Hal ini perlu dilakukan untuk melihat seberapa jauh mereka memahami masing-masing topik tersebut. Bila mereka dapat menjelaskan model bisnisnya dengan cukup baik namun tidak dapat menjelaskan pelaporan akuntansi dengan memadai maka mungkin ada diskonek atas keduanya bagi masyarakat.

c. Arsip - Tim program pengabdian kepada masyarakat kemudian juga akan mempelajari model catatan keuangan yang selama ini dibuat oleh masyarakat pengrajin kayu di Desa Grenden, Kabupaten Jember.

\section{Tahapan Pelatihan}

Tim program pengabdian kepada masyarakat kemudian memberikan pelatihan model akuntansi startup pada masyarakat pengerajin kayu Desa Grenden. Pelatihan berlangsung di Balai Desa dan berisi konsep serta pengetahuan umum terkait model akuntansi startup.

\section{Tahapan Pendampingan}

Tahap pendampingan dilakukan untuk menyesuaikan model akuntansi startup yang ada dengan kebutuhan khusus bengkel kerajinan kayu milik masyarakat pengerajin kayu di Desa Grenden. Tahap pendampingan ini dilakukan secara tidak terstruktur mengikuti kebutuhan dan ketersediaan waktu para pengerajin kayu.

\section{HASIL DAN PEMBAHASAN}

Program kegiatan pengabdian kepada masyarakat ini selesai dalam waktu 3 bulan yaitu sejak bulan Oktober hingga bulan Desember. Ada beberapa hal yang dicapai oleh kegiatan ini:

a. Pemahaman mengenai minat atas review kinerja dari UMKM di Desa Grenden.

b. Pengenalan model akuntansi startup pada pengerajin kayu di Desa Grenden.

\section{A. Pemahaman dan Antusiasme Konsep}

Pada tahap awal program pengabdian kepada masyarakat ini, kami menemukan bahwa masyarakat Desa Grenden, Kabupaten Jember memiliki pemahaman konsep bisnis yang cukup baik, khususnya di bidang pekerjaan mereka sebagai pengerajin kayu. Seperti pada umumnya pengusaha yang berawal dari bidang produksi, mereka tertarik dengan 
konsep bisnis yang langsung berkaitan dengan produk. Dalam hal ini adalah produk yang sedang mereka kembangkan yaitu alat permainan edukasi (APE).

Ini membuat mereka tertarik dengan model akuntansi startup. Hal ini dikarenakan model akuntansi ini menggunakan metriks atau ukuran berbasis bisnis sehingga lebih mudah dipahami dan digunakan bila dibandingkan dengan konsep akuntansi konvensional secara umum. ${ }^{7}$ Ini juga membuat mereka tertarik dengan prospek dan manfaat review kinerja yang bisa dihasilkan dengan menggunakan model akuntansi startup. Review kinerja yang baik akan dapat membantu mereka mengelola pengembangan dan perluasan bisnisnya serta merencanakan keputusan strategis ke depannya (Steve Blank dan Bob Dorf 2012, Steve Blank 2013, Boudreau 2018).

\section{B. Latar Belakang Kasus}

Dengan masyarakat pengrajin menganggap bahwa akuntansi startup merupakan konsep yang bagus dan mungkin akan berguna bagi perkembangan bisnis mereka maka pelatihan dan kemudian pendampingan akan lebih mudah dilakukan. Di sisi lain, masyarakat pengerajin kayu di Desa Grenden juga membutuhkan pelatihan dan pendampingan model akuntansi startup agar bisa mengelola dan merencanakan pengembangan usaha mereka dengan lebih baik.

Program pelatihan model akuntansi startup diselenggarakan di Balai Desa Grenden dan diikuti oleh sekitar 12 orang pengerajin kayu. Pelatihan ini menekankan pada konsep dan teori dasar model akuntansi startup serta manfaat yang mungkin diperoleh dengan menerapkan model akuntansi ini pada pengembangan bisnis mereka. Pada proses pendampingan berikutnya, kami bekerja lebih dekat dengan salah satu pengerajin kayu. Bengkel mitra ini menerima berbagai pekerjaan pesanan, khususnya terkait pengrajinan kayu dan mebel. Beliau mempekerjakan 3 - 5 orang di bengkelnya. Dia juga menerima pesanan kursi, meja, pintu, kusen jendela, dan sebagainya. Terkadang ada juga pesanan terkait bahan batu dan semen, entah itu untuk hiasan halaman maupun pondasi dan pelengkap pagar.

Berdasarkan skala pekerjaan, usaha bengkel kerajinan kayu mitra sudah cukup baik dan memiliki potensi untuk menjadi lebih maju. Kesulitan bengkel mitra untuk pengembangan usahanya adalah posisi usahanya yang berada di tempat yang aksesnya relatif terbatas ke pelanggan di luar daerah Grenden. Oleh karena itu, salah satu program pendampingan ini adalah mengembangkan akses usaha bengkel kerajinan kayu milik mitra ke pelanggan potensial yang lebih luas.

Ada 2 program pengembangan yang dilakukan:

a. Pengembangan Produk

Dalam program pengembangan produk, kami bersama dengan bengkel mitra mencoba mengembangkan produk alat permainan edukasi yang mudah diproduksi dan memiliki nilai jual cukup tinggi.

b. Pengembangan Pasar

Blank, Steve. 2010. "No Accounting for Startups". Blog post. Diunduh pada Oktober 2019 di https://steveblank.com/2010/02/22/no-accounting-for-startups/ 
Dalam program pengembangan pasar, kami bersama dengan bengkel mitra mencoba mengembangkan penjualan secara online. Hal ini diperlukan untuk membuka pasar yang lebih luas, menarik lebih banyak pelanggan, dan meningkatkan penjualan.

Kedua program pengembangan ini merupakan hal yang baru bagi bengkel mitra Dia belum pernah memproduksi dan menjual alat permainan edukasi sebelumnya dan dia juga belum pernah melakukan penjualan di dunia maya sebelum ini. Oleh karena itu, bengkel mitra memerlukan bantuan "alat" keuangan yang dapat memberi informasi bagaimana perkembangan dan kemajuan kedua program pengembangan tersebut.

Untuk itu kami mengajukan program pendampingan terkait akuntansi startup. Bila diterapkan dengan baik, model akuntansi startup ini dapat memberikan informasi yang berguna serta relatif mudah pula untuk digunakan. Oleh karenanya, tim pengabdian kepada masyarakat kemudian berdiskusi lebih lanjut dengan bengkel mitra untuk mendiskusikan potensi penggunaan model akuntansi startup secara lebih lanjut sebagai alat untuk mendukung kesuksesan kedua program pengembangan yang dilakukan oleh usaha bengkel kerajinan kayu milik mitra.

\section{Technology Acceptance Model (TAM)}

Program pengabdian kepada masyarakat ini menggunakan technology acceptance model (TAM) sebagai rerangka untuk melihat apakah model akuntansi startup ini akan berhasil digunakan dan berguna bagi usaha bengkel kerajinan kayu tersebut.

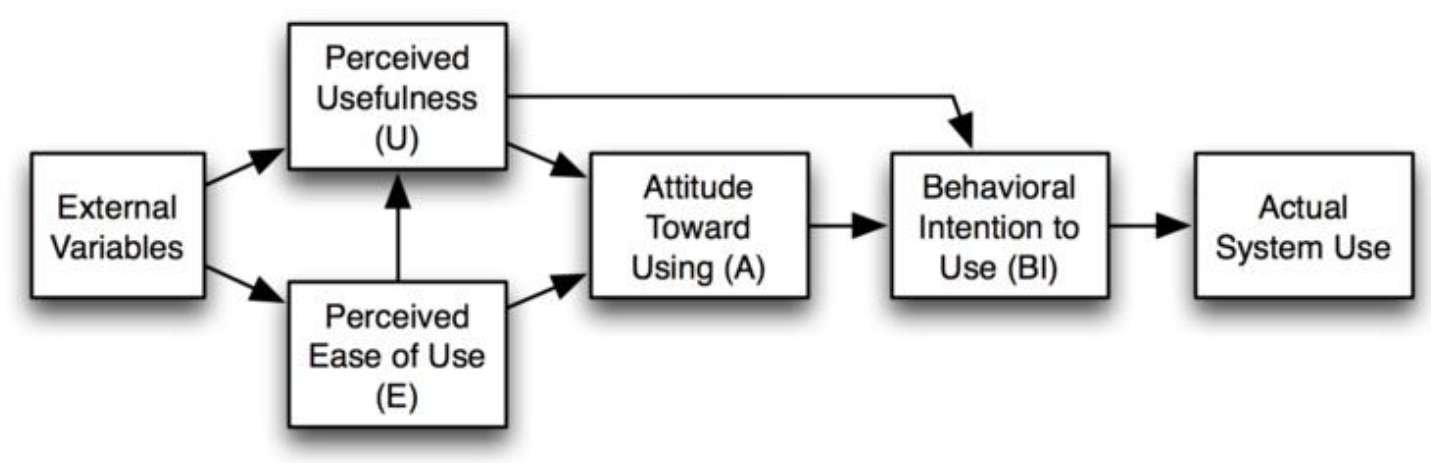

\section{Persepsi kebermanfaatan}

Pemilik usaha bengkel kerajinan kayu merasa bahwa model akuntansi startup sangat mungkin akan berguna bagi pengembangan usahanya. Ini khususnya bagi 2 program pengembangan yang sedang diusahakan. Metrik dalam model akuntansi startup akan memudahkan untuk melihat apakah program pengembangan yang dijalankan sudah berada di jalur yang benar. ${ }^{8}$

8 Blank, Steve. 2013. "Why the Lean Startup Changes Everything." Harvard Business Review. May 2013. 


\section{Persepsi kemudahan penggunaan}

Untuk persepsi kemudahan penggunaan, bengkel mitra tidak menilai model akuntansi startup cukup tinggi dalam aspek ini. Hal ini dikarenakan oleh beberapa alasan. Pertama, model akuntansi startup membutuhkan catatan yang relatif rapi. Ini menimbulkan sejumlah hambatan karena selama ini bengkel mitra tidak terbiasa membuat catatan terkait administrasi khusus terkait usahanya.

Kedua, bengkel mitra hanya memiliki catatan analog, dengan pulpen dan kertas tanpa ada prosedur khusus ataupun orang khusus yang menangani masalah administrasi, pembukuan, maupun keuangan. Sifat catatan ini adalah minimal. Ini menyulitkan usaha menerapkan model akuntansi startup karena lebih sulit menambahkan catatan baru dalam sistem analog yang mengandalkan kemampuan manusianya yang mana ini tidak dimiliki oleh bengkel mitra.

Hal ini menyebabkan bengkel mitra agak skeptis dalam menerapkan model akuntansi startup mengingat besarnya usaha dan ketidaknyamanan yang timbul karena penerapan model akuntansi startup ini. Sementara ia tidak memiliki alasan ataupun urgensi untuk menerapkan model akuntansi startup ini.

\section{KESIMPULAN}

Model akuntansi startup memiliki potensi manfaat yang besar bagi pengembangan usaha kecil. Namun di sisi lain, masih jarang digunakan untuk UMKM di Indonesia. Program pengabdian kepada masyarakat ini mencoba mengenalkan model akuntansi startup kepada salah satu usaha kecil di bidang kerajinan kayu di Desa Grenden, Kabupaten Jember.

Program pengabdian kepada masyarakat ini mengajukan 2 aspek model akuntansi startup untuk dinilai, yaitu persepsi kebermanfaatan dan persepsi kemudahan penggunaan. Namun hanya 1 aspek yang memiliki nilai positif dari mitra yaitu persepsi kebermanfaatan. Sementara untuk persepsi kemudahan penggunaan masih dianggap kurang memadai. Secara singkat, ini berarti mitra menganggap model akuntansi startup bermanfaat namun tidak terlalu mudah untuk digunakan. Hal ini dikarenakan adanya beberapa hambatan terkait kebiasaan membuat mauapun menggunakan informasi yang dianggap tidak urgen bagi usahanya.

Program pengabdian kepada masyarakat ini menyarankan lanjutan program dengan karakteristik usaha dan pengelola yang lebih sesuai untuk menerapkan model akuntansi startup seperti kecanggihan terkait teknologi informasi (technology savvy), mampu cepat menyesuaikan diri dan mempelajari hal baru, serta karakter lainnya. 


\section{DAFTAR PUSTAKA}

Arifin, Nurul. 2018. "Masih Banyak Pelaku UMKM ‘Buta' Akuntansi”. Kompas. Diakses pada Oktober 2019 https://ekonomi.kompas.com/read/2018/08/30/144531526/masih-banyak-pelakuumkm-buta-akuntansi

Blank, Steve. 2010. "No Accounting for Startups". Blog post. Diunduh pada Oktober 2019 di https://steveblank.com/2010/02/22/no-accounting-for-startups/

Blank, Steve. 2013. "Why the Lean Startup Changes Everything." Harvard Business Review. May 2013

Blank, Steve and Bob Dorf. 2012. The Startup's Owner Manual: The Step-By-Step Guide for Building a Great Company. K\&\&S Ranch

Boudreau, Kevin. 2018. "Notes on Designing Your Company.” Harvard Business School Strategy Unit. Working Paper No. 16-131

Xi, Guoqian. 2017. "How Does Firm Survival Differ between Business Takeovers and New Venture Start-Ups.” IZA Discussion Paper. No. 11155. 